\title{
AN ANALYSYS OF THE ASSESSMENT OF TAXABLE EARNINGS IN GERMANY
}

\author{
Stephan Meyering \\ University of Hagen, Hagen, Germany \\ ORCID: http:/ / orcid.org/0000-0002-8610-8682 \\ Matthias Groene \\ University of Hagen, Hagen, Germany
}

\begin{abstract}
The assessment of taxable earnings is of fundamental importance for the corporate tax burden. Therefore it is often subject of political discussions and is either witnessing a constant process of change. Against this background, the aim of this paper is to analyse the structure of the assessment of taxable earnings in Germany. This can be used to obtain information on the possibilities for future national developments in Russia. We start with an overview of the areas of application of the different methods for the assessment of earnings. It shows that the complete comparison of a company's operating assets (so-called tax balance sheet) and the statement based on the net income method are the most important methods. The fundamental difference between this two methods: the statement based on the net income method is controlled by the inflow and outflow principle (flow value statement), the stock value statement, which makes it necessary to draw up two balance sheets (one at the start of the year and one at the end of the year, underlies the comparison of the company's operating assets. Therefore the analysis focuses on these two methods. It shows, that the complete comparison of a company's operating assets is more accurate but although much more costly than the statement based on the net income method. The analysis is supported by practical examples, which are also used to illustrate the differences between the two main methods.
\end{abstract}

KEYWORDS taxes; taxable earnings; balance sheet, German income tax act; statement based on the net income method

\section{HIGHLIGHTS}

1. The complete comparison of a company's operating assets (so-called tax balance sheet) and the statement based on the net income method are the most important methods of the assessment of taxable earnings in Germany

2. The complete comparison of a company's operating assets is more accurate but although much more costly than the statement based on the net income method

3. The inventory of the structure of the assessment of taxable earnings in Germany can be used to obtain information on the possibilities for future national developments in Russia

\section{МЕТОАЫ ОЦЕНКИ НАЛОГООБААГАЕМОЙ ПРИБЫАИ В ГЕРМАНИИ}

\author{
Стефан Мейеринг \\ Университет Хаген, г. Хаген, Германия \\ ORCID: http://orcid.org/0000-0002-8610-8682 \\ Матиас Гроен \\ Университет Хаген, г. Хаген, Германия
}

\begin{abstract}
АННОТАЦИЯ Оценка налогооблагаемой прибыли имеет важнейшее значение для налоговой нагрузки в сфере бизнеса и поэтому является предметом политических дискуссий и претерпевает постоянные изменения. С учетом актуальности проблемы, сформулирована цель исследования: анализ законодательно установленных методов оценки налогооблагаемой прибыли в Германии, их достоинств и недостатков, а также особенностей их практического применения.
\end{abstract}


Данный анализ может быть использован для изучения перспектив совершенствования налоговой системы и развития бизнеса в России. В статье рассматриваются сферы применения различных методов оценки прибыли. Выявлено, что важнейшими из них являются метод полного сравнения операционных активов компании (налоговый баланс) и метод основанный на оценке чистой прибыли. Главное отличие этих методов в том, что первый построен на основе сопоставления балансов на начало и конец года, что и позволяет сравнивать операционные активы, а второй базируется на принципе денежного потока (поступления и расходования денежных средств). В работе подробно описывается применение указанных методов. Проведенный анализ показал, что сравнение операционных активов компании является более точным методом, хотя и гораздо более дорогостоящим, чем отчетность, основанная на методе чистой прибыли. Анализ подтверждается практическими примерами

КЛЮЧЕВЫЕ СЛОВА Налоги, налогооблагаемая прибыль, Баланс, Закон о налоге на прибыль в Германии, отчетность, основанная на методе чистой прибыли

\section{ОСНОВНЫЕ ПОЛОЖЕНИЯ}

1. Основными методами оценки налогооблагаемой прибыли в Германии являются метод полного сравнения операционных активов компании (так называемый налоговый баланс) и метод основанный на оценке чистой прибыли

2. Полное сравнение операционных активов компании является более точным, хотя и гораздо более дорогостоящим, чем отчетность, основанная на методе чистой прибыли

3. Исследование методов оценки налогооблагаемой прибыли в Германии может быть использовано для совершенствования налоговой системы и развития бизнеса в России

\section{Introduction}

The assessment of taxable earnings is used to determine the earnings that will be the basis of assessment for taxation purposes with regard to profit income types. The assessment is of fundamental importance for the corporate tax burden. Therefore it is often subject of political discussions and is either witnessing a constant process of change. This provides a motive for examining the assessment of taxable earnings in other countries. Doing so, clues on the possibilities for future national developments can be obtained. The aim of this paper is to analyse the structure of the assessment of taxable earnings in Germany.

We contain the paper on the so-called profit incomes. These consist of incomefrom trade or business enterprises, income from agriculture and forestry and income from self-employment (Section 2 (2) (1) (1) of the German Income Tax Act $\left.(\mathrm{EStG})^{1}\right)$.

1 The Federal Ministry of Justice and Consumer Protection provides virtually all of the latest Federal laws free of charge on its website at http:// www.gesetze-im-internet.de/. Here you can retrieve the various laws and ordinances, as amended. Certain laws can also be retrieved in English by selecting "Translations" from the menu.
There are a number of different methods available for the assessment of taxable income, the areas of application for which are described in greater detail further. This relates in particular to the complete comparison of the company's operating assets (so-called tax balance sheet), the incomplete comparison of the company's operating assets, statements based on the net income method, the assessment of earnings according to average rates and the assessment of earnings by the tonnage.

The area of application of the various methods for the assessment of earnings is primarily determined by whether the party subject to taxation in question is a trade or business enterprise. A trade (and, thus, a trade or business enterprise) can be operated by means of commercial certification or by means of certain legal forms. If a trade or business enterprise is established, the method to be applied for the assessment of taxable earnings shall be in accordance with a legal obligation to keep records. This may arise either from non-fiscal provisions (including in particular from the German Commercial Code (HGB)) or from fiscal provisions (Section 141 of the German Fiscal Code 
(AO)): All traders within the meaning of Section 1 et seq. of the German Commercial Code (HGB) shall be subject to a legal obligation to keep records according to the German Commercial Code; this shall include all tradespeople who are not already regarded as traders and exceed certain size characteristics according to fiscal provisions. Parties subject to taxation who have a legal obligation to keep records must assess their earnings using the complete comparison of the company's operating assets, whilst also taking into account the various principles under commercial law (so-called authority, for more information see Section 2.1) ${ }^{2}$. If there is no resulting legal obligation to keep records and accounts are not maintained on a voluntary basis, earnings must be assessed using the statement based on the net income method ${ }^{3}$.

Non-traders within the context of the assessment of earnings include selfemployed individuals and farmers and foresters. Self-employed individuals are individuals who are aiming to achieve sustainable profit, predominantly through their own efforts, without being dependent on receiving instructions, and acting at their own expense and risk. Commercial law does not stipulate any legal obligation to keep records for these individuals. If they maintain their accounts on a voluntary basis, they must assess their earnings using the incomplete comparison of the company's operating assets, or, in all other cases, they must do this using the statement based on the net income method. As for farmers and foresters, there is a legal obligation to keep tax records according to Section 141 of the

2 Traders who do not exceed specific size characteristics in accordance with Section 241a of the German Commercial Code (HGB) and are not obliged to keep records according to Section 141 of the German Fiscal Code (AO) are an exception to this. They are entitled to assess their earnings using the statement based on the net income method.

${ }^{3}$ If a trade or business enterprise operates commercial vessels in international traffic, there is the option available on request, in accordance with Section 5a of the German Income Tax Act (EStG), to assess earnings according to the tonnage carried during the course of operation, this applying by way of derogation from the principles stated above.
German Fiscal Code (AO), assuming they do not exceed the size characteristics laid down therein or maintain their accounts on a voluntary basis. In such cases, they must assess their earnings using the incomplete comparison of the company's operating assets. If the accounts are not maintained, earnings must in principle be assessed using the statement based on the net income method ${ }^{4}$.

Below is a detailed explanation of the complete comparison of the company's operating assets and the statement based on the net income method, both of which are the most important methods for the assessment of earnings. The assessment of earnings by tonnage and the assessment of earnings according to average rates are no longer taken into account below as a result of their limited area of application. The incomplete comparison of the company's operating assets does not require any further consideration either as it is virtually identical to the complete comparison of the company's operating assets [1-3].

\section{Analysys of the complete comparison of the company's operating assets}

Principles. The complete comparison of the company's operating assets (so-called tax balance sheet) stipulates the balance sheet-oriented assessment of earnings, i.e. earnings are calculated as the difference between the operating assets at the end and at the start of a financial year (Section 4 (1) (1) of the German Income Tax Act (EStG)). The operating assets are made up of components that increase their value on the one hand and reduce their value on the other hand. The components increasing the value of operating assets are referred to as assets. These include active assets (referred to under commercial law as assets) and deferred expenses and accrued income; passive assets (referred to under commercial law as liabilities) and deferred income and accrued expenses function as liabilities that reduce the value of operating assets. The difference between the two is the equity,

${ }^{4}$ If the special provision stated in Section $13 a$ of the German Income Tax Act (EStG) applies, earnings may also be assessed using average rates. 
which is also referred to as net assets. This is highlighted in the following Figure:

Assets balance sheet for the 31/12/17 Liabilities

\begin{tabular}{|c|c|}
\hline \multirow{2}{*}{ Active assets } & $\begin{array}{c}\text { Equity } \\
\text { (= net income) }\end{array}$ \\
\cline { 2 - 2 } & Passive assets \\
\hline Active accruals & Passive accruals \\
\hline
\end{tabular}

Earnings are represented by the change in value between equity at the end of a given year compared to the start of the financial year. Accordingly, the assessment of earnings is performed using stock values as opposed to flow values. The following example highlights this, whereby earnings total $€ 5 \mathrm{k}$ (53-48):

Assets Balance sheet for the 31/12/01 (in T€) Liabilities

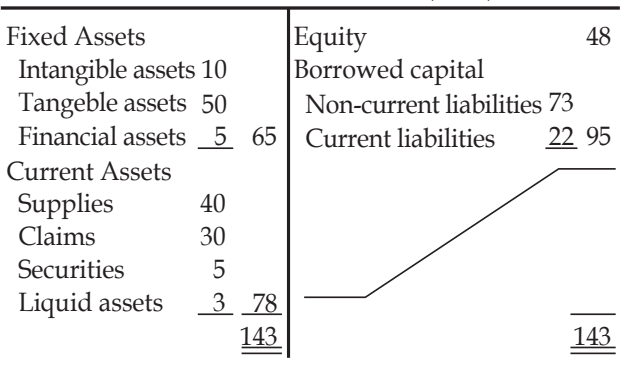

Assets Balance sheet for the 31/12/02 (in T€) Liabilities

\begin{tabular}{lrl|ll}
\hline Fixed Assets & & Equity & \\
Intangible assets & 8 & & Borrowed capital & \\
Tangeble assets & 55 & & Non-current liabilities 69 \\
Financial assets & $\underline{5}$ & 68 & Current liabilities & $\underline{18} 87$ \\
Current Assets & & & \\
Supplies & 42 & & \\
Claims & 25 & & \\
Securities & 5 & & \\
Liquid assets & $\underline{4} \underline{\underline{7140}}$ & &
\end{tabular}

The provisions regarding the scope of the operating assets to be recognised (accounting on its merits; for more information see Section 3.2) and their valuation (accounting by value; for more information see Section 3.3) are subject to the various commercial provisions in place. This is referred to as authority [4, p. 138; 5]. Accordingly, the various commercial accounting provisions are authoritative for the tax balance sheet unless they contradict the fiscal standards in place (Section 5 (1) (1) of the German Income Tax Act (EStG)). However, if there are indeed such standards in place, regardless of wheth- er they are structured as an option or as a mandatory standard, then they shall override any commercial provisions in place (accounting and/or valuation reserves). This authority has always been subject to extensive discussions with regard to its grounds and scope [6, pp. 324-326; 7]. Lawmakers have resolutely abided by this authority to the present day, although it has been increasingly eroded away in recent times past.

Accounting on its merits. Accounting on its merits determines the scope of the operating assets to be accounted for. As illustrated above, this involves active and passive assets as well as deferred expenses and accrued income and deferred income and accrued expenses. These are all illustrated below.

The term "active asset" is not defined by law. The company assumes active assets are involved if there are economic values which can be estimated independently and can also be transferred individually or together with the company [8-11]. This results in a large group of potential active assets which can be systematised according to a number of different criteria. The respective form with regard to the individual criteria will in turn primarily determine the provisions to be applied for the valuation. A distinction is made between the following criteria and associated forms [12-14]:

\begin{tabular}{|l|l|}
\hline \multicolumn{1}{|c|}{ Criterion } & \multicolumn{1}{c|}{ Forms } \\
\hline Depreciability & $\begin{array}{l}\text { Depreciable versus } \\
\text { non-depreciable }\end{array}$ \\
\hline $\begin{array}{l}\text { Acquisition, i.e. access } \\
\text { to operating assets }\end{array}$ & $\begin{array}{l}\text { Acquisition versus } \\
\text { production }\end{array}$ \\
\hline Mobility & $\begin{array}{l}\text { Movable versus } \\
\text { immobile }\end{array}$ \\
\hline Materiality & $\begin{array}{l}\text { Tangible versus } \\
\text { intangible }\end{array}$ \\
\hline Purpose & $\begin{array}{l}\text { Fixed assets versus } \\
\text { current assets }\end{array}$ \\
\hline
\end{tabular}

It should be noted that active assets do not need to be recognised (option) if their net value is no more than $€ 410$ (Section 6 (2a) of the German Income Tax Act (EStG); so-called low-value assets). An explicit recognition ban is applicable to intangible fixed assets acquired free of charge (Section 5 (2) of the German Income Tax Act (EStG)). 
The term "passive asset" is not legally codified either. A passive asset shall be assumed in the literature if there is a legal or de facto obligation to third parties which results in an economic burden and which was earned or incurred during the course of the past financial year, assuming the occurrence and utilisation of such a liability is indeed likely [14-17]. If the situation involves an obligation that is secure both on its merits as well as by value, this is referred to as a liability, or a provision in all other cases [18]. The law stipulates a number of special regulations for recognising provisions which are merely referred to here (see: Section $5(2 a-4 b)$ of the German Income Tax Act (EStG)).

Deferred expenses and accrued income refer to payments made prior to the reporting date that will only constitute expenses a specific period of time after the reporting date (Section 5 (5) of the German Income Tax Act (EStG)). The corresponding situation applies to deferred income and accrued expenses. Classic application scenarios for accruals and deferrals arise in the case of long-term debt obligations for which payments have been made and/or sent in advance (such as lease agreements where the reporting party is a tenant or landlord).

Accounting by value. Accounting by value governs the valuation of active and passive assets to be recognised (accruals and deferrals are not subject to any valuation). The valuation may be split into the initial valuation and the subsequent valuation. While the initial valuation relates to the valuation of the asset in question upon initial recognition, the subsequent valuation governs the valuation conducted in subsequent years until the asset is retired from the operating assets. The valuation of active and then passive assets is illustrated to begin with below.

With regard to the initial valuation of active assets, the law in force stipulates two primary valuation criteria in the form of procurement costs and production costs (Section 6 (1) (1) of the German Income Tax Act (EStG)).

The acquisition costs are therefore relevant in the event of an acquisition. By definition, they are made up of all of the payments individually attributable to the asset in question that were necessary to acquire the asset in question and transform it into an operationally ready state (Section 255 (1) of the German Commercial Code (HGB)). The following cost components specified in detail are attributed to them:

\begin{tabular}{|ll|}
\hline & Acquisition price \\
.$/$ & Acquisition price reductions \\
+ & Incidental acquisition costs \\
+ & Subsequent acquisition costs \\
\hline$=$ & Acquisition costs \\
\hline
\end{tabular}

The following example highlights this:

Tradesperson $\mathrm{L}$ acquires a machine from the USA at a net purchase price of $€$ 200,000 in January of year 1 . The following additional costs are also incurred in conjunction with this acquisition:

- Freight costs ex-works $€ 3,000$;

- Duty $€ 10,000$;

- Import sales tax € 38,000;

- Concrete foundations for the machine (directly attributable): $€ 4,000$.

The purchase price is paid by way of exchange, with the remaining costs being paid by cheque and/or cash. The exchange total of $€ 226,000$ includes bill discounting and fees of $€ 26,000$. The general administration costs incurred as a result of the purchase negotiations totalled $€ 3,000$.

$\mathrm{L}$ is able to deduct the import sales tax from his sales tax liability in accordance with Section 15 (1) (2) of the German Turnover Tax Act (UStG). The ordinary useful life of the machine is 4 years.

Determination of acquisition costs: In addition to the purchase price, the ancillary costs that are financially linked to the purchase directly also form part of the acquisition costs for an asset. However overheads, including any administrative overheads, do not form part of the acquisition costs. The import sales tax deductible as input tax does not form part of the acquisition costs either. However, duty does indeed form part of the incidental acquisition costs. Bill discounting and fees are considered to be financing costs as opposed to acquisition costs for the acquired asset.

The acquisition costs for the machine can be determined as follows: 


\begin{tabular}{|c|c|c|}
\hline Bill amount & & $€ 226,000$ \\
\hline Financing costs & & $€ 26,000$ \\
\hline Net purchase price & & $€ 200,000$ \\
\hline $\begin{array}{l}\text { Incidental acquisition } \\
\text { costs }\end{array}$ & & \\
\hline Freight & $€ 3,000$ & \\
\hline Duty & $€ 10,000$ & \\
\hline Concrete foundations & $€ 4,000$ & $€ 17,000$ \\
\hline $\begin{array}{l}\text { Acquisition costs } \\
\text { within the meaning of } \\
\text { Section } 6(1)(1) \text { of the } \\
\text { German Income Tax } \\
\text { Act (EStG) }\end{array}$ & & $€ 217,000$ \\
\hline
\end{tabular}

On the contrary, production costs shall be authoritative if the assets have been produced in-house. By definition, these production costs include all disbursements resulting from the consumption of goods and the use of services for the production of an asset, its expansion or a substantial improvement beyond its original condition (Section 255 (2) of the German Commercial Code (HGB)). Unlike acquisition costs, there is no restriction on direct costs, meaning therefore that productionrelated overheads can be included, whereas there is an inclusion option for non-production-related overheads and capitalised interest under certain circumstances as well [19]. The inclusion options must therefore be exerted in accordance with the commercial balance sheet (Section 6 (1) (1b) of the German Income Tax Act (EStG)). Details of the cost components can be found in the following Figure:

\begin{tabular}{|c|c|c|}
\hline \begin{tabular}{|l|} 
Produc- \\
tion- \\
related \\
direct costs \\
\end{tabular} & $\begin{aligned} & \text { Direct material costs } \\
+ & \text { Direct production costs } \\
+ & \text { Special direct } \\
& \text { production costs }\end{aligned}$ & \multirow{2}{*}{$\begin{array}{l}\text { Inclu- } \\
\text { sion } \\
\text { obli- } \\
\text { gation }\end{array}$} \\
\hline \begin{tabular}{|l|} 
Produc- \\
tion- \\
related \\
overheads \\
\end{tabular} & $\begin{array}{l}\text { + Material overheads } \\
+ \text { Production overheads } \\
+ \text { Depreciation of fixed } \\
\quad \text { assets }\end{array}$ & \\
\hline $\begin{array}{l}\text { Non-pro- } \\
\text { duction- } \\
\text { related } \\
\text { overheads }\end{array}$ & $\begin{array}{l}+ \text { Administrative costs } \\
+ \text { Costs of social amenities } \\
+ \text { Costs of voluntary } \\
\text { social benefits } \\
+ \text { Costs for the company } \\
\text { pension scheme }\end{array}$ & \multirow[t]{2}{*}{$\begin{array}{l}\text { Inclu- } \\
\text { sion } \\
\text { option }\end{array}$} \\
\hline $\begin{array}{l}\text { Financing } \\
\text { costs }\end{array}$ & + Capitalised interest & \\
\hline & $=$ Production costs & \\
\hline
\end{tabular}
this:
The following costs are reported in a cost allocation sheet for year 1 (in $€$ million):

Raw materials 200

Auxiliary and operating $\quad 20$

materials

Warehousing, material transport $\quad 20$

and testing,

including any personnel

expenses incurred

Production department wages

and salaries:

production wages $\quad 150$

salvage remuneration $\quad 40$

salaries $\quad \underline{50}$

240

Employer contributions to social security scheme attributable to

the Production department:

accruing to Production wages 30

accruing to salvage 8

remuneration

accruing to salaries

$=$ Subtotal

Depreciation on production

facilities:

scheduled depreciation

(normal allowance for

depreciation)

unscheduled depreciation $\quad 20$

additional imputed

depreciation on the difference

between replacement costs and acquisition costs of the assets

Interest rates:

capitalised interest directly

attributable to products

other capitalised interest

imputed capitalised interest

140

Taxes:

$$
\text { corporation tax }
$$

business tax

Voluntary company pension scheme

General administration costs $\quad 400$

Distribution costs $\quad 150$

$=$ Total costs in year 1 :

1,558

A total of 100,000 manufactured goods have been made in year 1 . As of 31/12/01, the reporting date, there were still 10,000 units of these manufactured goods stored in the warehouse. It can therefore be assumed that the manufactured products stored in the warehouse incurred, on average, the same manufacturing costs per unit as the average of all manufactured products made in year 1 . 
Determination of production costs: a) Lower value limit (inclusion obligations): The lower value limit is made up of the material and production costs, which in turn are made up of the direct costs and overheads. This also includes the depreciation of fixed assets, insofar as such depreciation is caused by production. The depreciation of fixed assets is represented by scheduled depreciation, as opposed to unscheduled depreciation and imputed depreciation.

Accordingly the lower value limit is made up of the following (in $€$ million):

Raw materials

Auxiliary and operating

materials

Warehousing, material transport and testing, including any

personnel expenses incurred

$=$ Material costs

Production department wages and salaries

Employer contributions to social security scheme attributable to the Production department

Scheduled depreciation on

production facilities

$=$ Production costs

$=$ Lower value limit of all

manufactured goods made in

year 1

$=$ Lower value limit of the

manufactured goods present on

$31 / 12 / 01(10 \%$ * $628=)$

b) Upper value limit = lower value limit plus inclusion options

Options exist for the following costs (in $€$ million):

General administration costs

Voluntary company pension scheme

Capitalised interest directly

attributable to products

$=$ Costs to be included

$€ 51$ million worth of these costs are products still present as at the reporting date $(=10 \%$ * 510).

The upper value limit is made up of the costs subject to mandatory inclusion and the costs to be included. It therefore totals $€ 113.8$ million $(=62.8+51)$.

The following costs arising in this particular case must not be included in the production costs:

- unscheduled depreciation;
- imputed depreciation (this involves a profit element according to the nominal value principle);

- interest not directly attributable to the goods;

- imputed capitalised interest (profit element);

- corporation tax (not accounted for production, but rather for taxable earnings);

- business tax (not accounted for production);

- distribution costs.

The acquisition and/or production costs are subject to depreciation losses at the level of the subsequent valuation of active assets (mostly referred to in tax legislation as allowance for depreciation (AfA = Absetzung für Abnutzung)). This can be differentiated in the form of scheduled and unscheduled depreciation. Scheduled depreciation must therefore be effected solely on depreciable assets. This results in the acquisition and/or production costs being spread over the period of time that the assets form part of the operating assets (Section 7 (1) (1) of the German Income Tax Act (EStG)). In order to define this period of time, reference is typically made in practice to so-called "allowance for depreciation" (AfA) tables published by the tax authorities, which contain standardised useful lives for different assets. Unscheduled depreciated may be effected on all active assets, subject to certain conditions applying. This results in a one-off reduction in value which can be attributable to exceptional technical or economic wear or to lower acquisition or sales prices. The provisions regarding the effecting of unscheduled depreciation are particularly differentiated and are regularly the subject of disputes between parties subject to taxation and tax authorities [20].

The acquisition and/or production costs are also relevant to passive assets with regard to the initial valuation. However, given that there is no acquisition and/or production of these assets in the literal sense, reference is instead also made to the basis of the settlement value in accordance with commercial law. This is the amount that is required to settle the underlying 
liability. In the case of monetary payment obligations, this amount corresponds to the nominal amount, whereas for payment in kind obligations it corresponds to the respective amount required to settle the liability whilst taking into account all production-related direct costs and overheads based on current price and cost ratios. If the residual term of passive assets is more than 12 months, the assets in question must be discounted using an interest rate of $5.5 \%$ (Section 6 (1) (3) (1), No. 3a, Bs. e) (1) of the German Income Tax Act (EStG)). The tax deferral effect, i.e. the benefit resulting from the fact that a tax payment is only made at a later date, is compensated for here by way of the premature profit-reducing allocation. As part of the subsequent assessment, passive assets must be depreciated in an unscheduled manner under certain circumstances if the value on the reporting date exceeds the settlement value entered previously.

\section{Analysys of the of the statement based on the net income method}

With regard to the statement based on the net income method, earnings are calculated as the surplus of operating income net of operating expenses (Section 4 (3) of the German Income Tax Act (EStG)).

\begin{tabular}{|ll|}
\hline & Total of all operating income \\
.$/$ & Total of all operating expenses \\
\hline$=\quad$ & Earnings (Section 4 (3) of the \\
German Income Tax Act (EStG))
\end{tabular}
this:

The following example highlights

A tax adviser has the following income and expenses during the course of a calendar year:

\section{Income:}

January to December: Regular consultancy fees:

March: Receipt of consultancy fee charged the previous year:

August: Reimbursed income tax for the year:

September: Proceeds from the sale of a $€ 100$ PC to be posted (acquisition costs which have not yet had a profit-reducing effect by way of "allowance for depreciation" (AfA)):
December: Advance for a legal

challenge yet to be made: 400

Expenses:

January to December: Office rent:

$€ 36,000$

January to December: Salaries and

ancillary costs:

$€ 270,000$

January to December: Office

materials and other costs (office

cleaning, lighting, heating etc.):

January to December: Life

insurance and health insurance

contributions for the tax

consultant and his wife:

February: Acquisition of undeveloped plot of land for a

separate office building:

March: Loan repayment for a

professional loan:

March: Interest on loans for the months of January to March of year 12 (for a professional loan):

June: Acquisition of a PC

(expected useful life of 3 years):

June: Acquisition of several

low-value assets with respective acquisition costs of less than $€ 150$ :

The tax consultant's earnings from freelance work are calculated using a statement based on the net income method (Section 4 (3) of the German Income Tax Act (EStG)):

Income

Consultancy fees

481,300

Sales proceeds PC

Total income 481,600

./. Expenditure

"Book value" of sold PC 100

Office rent $\quad 36,000$

Salaries $\quad 270,000$

Office materials and other $\quad 14,500$

expenses

Interest on loans $\quad 500$

Low-value assets $\quad 1,600$

Acquired PC

Procurement costs June $12 \quad 3,000$

./. Allowance for depreciation for 7 months:

$3,000 .: 3 * 7 / 12$

$\underline{583} \quad \underline{583}$

Total expenditure

$\underline{323,283}$

158,317

$=$ Profit

Notes to operating income:

- the consultancy fees totalling $€ 481,300$ are made up of current earn$€ 300$ ings for the calendar year, earnings from 
the previous year 10 (accrual principle; Section 11 of the German Income Tax Act (EStG)) and advances;

- the reimbursed income tax is a personal tax. It is to be recognised neither as an operating expense upon payment, nor as operating income upon reimbursement (Section 12 (3) of the German Income Tax Act $(\mathrm{EStG}))$. The entire sales proceeds for the PC are counted as income, whereas the acquisition costs (book value) not yet asserted during the course of the "allowance for depreciation" (AfA) are, however, counted as operating expenses.

Notes to operating expenditure:

- the residual value of the PC must be treated as an expense with a profit-reducing effect. The payments actually made for the office rent, salaries and office materials are also deductible as operating expenses. The life insurance and health insurance contributions are not to be taken into account as operating expenses. They are private expenses. The acquisition costs for the land shall only be recognised as operating expenses in accordance with Section 4 (3) (4) of the German Income Tax Act (EStG) at the time of any subsequent sale or extraction. The sales proceeds must therefore be treated as income accordingly;

- the loan repayment does not constitute an operating expense; taking out a loan is even less regarded as operating income. The interest on loans for the loan taken out for commercial purposes shall be deductible as operating expenses;

- low-value assets are deducted with immediate effect as operating expenses in accordance with Section 4 (3) in conjunction with Section 6 (2) of the German Income Tax Act (EStG);

- the new PC is one of the depreciable assets whose acquisition costs are to be spread over the useful life during the course of the allowance for depreciation (AfA = Absetzung für Abnutzung). Given the acquisition took place in June of the year in question, linear depreciation is only taken into account for a period of 7 months according to Section 7 (1) (1) and (4) of the German Income Tax Act (EStG).
This refers to operating income and/or expenses which are incurred in money or in monetary equivalents [21-22]. They must be recognised at the time of their inflow so that a payment-based assessment of earnings can be made. The assessment of earnings is therefore performed here using flow values. This merely requires the simple recording of all operating income and operating expenses so that no accounting is required, unlike the complete comparison of the company's operating assets. As a result, the statement based on the net income method makes things significantly easier for the parties subject to taxation in question.

The payment-based assessment is however broken down by various special provisions. The most important one relates to disbursements for the acquisition of fixed assets and certain current assets (Section 4 (3) (3) of the German Income Tax Act (EStG)). With regard to depreciable assets, these are only taken into account in a profit-reducing manner over the useful life, whereas for non-depreciable assets, they are only taken into account when the asset is retired from the operating assets. These special provisions reduce the volatility of the measurement base by ensuring high-value disbursements do not merely cause a substantial reduction in earnings and a corresponding reduction in the tax burden at a specific time.

The fundamental difference between the statement based on the net income method according to Section 4 (3) of the German Income Tax Act (EStG) and the assessment of earnings by way of comparison of the company's operating assets: The statement based on the net income method is controlled by the inflow and outflow principle (flow value statement). However, a stock value statement, which makes it necessary to draw up two balance sheets (one at the start of the year and one at the end of the year, underlies the comparison of the company's operating assets.

\section{Conclusions}

The assessment of taxable earnings in Germany stipulates a number of different methods for the assessment of earnings whose areas of application dif- 
fer between the various parties subject to taxation. A trade or a business enterprise which have a legal obligation to keep records must assess their earnings using the complete comparison of the company's operating assets. On the other hand, the non-traders usually use the statement based on the net income method to assess the earnings.

The greatest significance between this two methods is attributed to the complete comparison of the company's operating assets (so-called tax balance sheets), which stipulate a balance sheet-based assessment of earnings based on differentiated provisions. These provisions vary due to the different components of the tax balanced sheet (active assets, passive assets and accruals) and their individual characteristics. Furthermore, it could be shown that the complete comparison of the company's operating assets is embossed by the commercial accounting of the German Commercial Code.

On the contrary, the payment-based statement based on the net income methods has the effect of significantly simplifying the assessment of earnings, but is only open to parties subject to taxation who earn a low level of income.

\section{References}

1. Meurer I. Section 4 of the German Income Tax (EStG). Lademann: Kommentar zum Einkommensteuergesetz, Stuttgart, 2016, actualization no. 224, marginal no. 46.

2. Pickert G. Gelten die handelsrechtlichen GoB auch für die steuerbilanzielle Gewinnermittlung nach § 4 Abs. 1 EStG? Deutsches Steuerrecht, 1989, vol. 27, no. 12, pp 374-378.

3. Wied E. Section 4 of the German Income Tax (EStG). Blümich: Einkommensteuergesetz (EStG), München, 2016, actualization no. 130, marginal no. 119.

4. Hennrichs J. Der steuerrechtliche sog. Maßgeblichkeitsgrundsatz - Stand und Perspektive, Steuer und Wirtschaft, 1999, vol. 76, no. 2, pp. 138-153.

5. Krumm M. Section 5 of the German Income Tax (EStG). Blümich: Einkommensteuergesetz (EStG), München, 2016, actualization no. 130, marginal no. 150.

6. Gräbe S. Das Maßgeblichkeitsprinzip vor dem Hintergrund des BilMoG. Berlin, 2012.

7. Wehrheim M., Fross I. Wider die Aushöhlung des Maßgeblichkeitsprinzips. Steuer und Wirtschaft, 2010, vol. 87, no. 2, pp. 195-203.

8. Federal Court of Finance (BFH). Judgement dated 10/08/1989, file number X R 176177/87. Bundessteuerblatt II, 1990, pp. 15-17.

9. Hoffmann W.-D. Section 4, 5 of the German Income Tax (EStG). Littmann/Bitz/Pust: Einkommensteuergesetz (EStG), Stuttgart, 2016, actualization no. 116, marginal no. 599.

10. Moxter A. Bilanzsteuerrecht. Tübingen, 2007.

11. Plewka H., Schmidt L. Section 5 of the German Income Tax (EStG). Lademann: Kommentar zum Einkommensteuergesetz, Stuttgart, 2016, actualization no. 224, marginal no. 676.

12. Hoffmann W.-D. Section 4, 5 of the German Income Tax (EStG). Littmann/Bitz/ Pust: Einkommensteuergesetz (EStG), Stuttgart, 2016, actualization no. 116, marginal no. $604-609 \mathrm{~d}$.

13. Plewka H., Schmidt L. Section 5 of the German Income Tax (EStG). Lademann: Kommentar zum Einkommensteuergesetz, Stuttgart, 2016, actualization no. 224, marginal no. 680.

14. Scheffler W. Besteuerung von Unternehmen II. Heidelberg, 2014.

15. Federal Court of Finance (BFH). Judgement dated 20/01/1983, file number X IV R 168/81. Bundessteuerblatt II, 1983, pp. 375-378.

16. Hoffmann W.-D. Section 4, 5 of the German Income Tax (EStG). Littmann/Bitz/Pust: Einkommensteuergesetz (EStG), Stuttgart, 2016, actualization no. 116, marginal no. 869.

17. Thies A. Rückstellungen als Problem der wirtschaftlichen Betrachtungsweise. Frankfurt, 1996.

18. Patek G. Steuerliche Ergebnisermittlung der Unternehmen. Berlin, 2015.

19. Meyering S., Groene M. Die Neuregelung zu den Bestandteilen der steuerlichen Herstellungskosten - Wünschenswerte Reaktivierung der (umgekehrten) Maßgeblichkeit? Deutsches Steuerrecht, 2016, vol. 54, no. 29, pp. 1696-1702.

20. Meyering S., Groene M. Portheine Kea: Das BMF-Schreiben zur Teilwertabschreibung wegen voraussichtlich dauernder Wertminderung - Überblick und konzeptionelle Würdigung. Deutsche Steuer-Zeitung, 2015, vol. 103, no. 3, pp. 84-93.

21. Federal Court of Finance (BFH). Judgement dated 06/10/2004, file number XR 3603. BFH/NV, 2005, pp. 682-688. 
22. Federal Court of Finance (BFH). Judgement dated 06/10/2004, file number XR 3603. BStBl. II, 1979, pp. 700-702.

AUTHORS Stephan Meyering - Doctor of Economic Science, Professor, Head of the Chair of Business Taxation, University of Hagen, Hagen, Germany (65 Universitaetsstraße, 58084, Hagen, Germany); ORCID: http://orcid.org/00000002-8610-8682; e-mail: stephan.meyering@fernuni-hagen.de

Matthias Groene - Master of Economic Science, Chair of Business Taxation, University of Hagen, Hagen, Germany (65 Universitaetsstraße, 58084, Hagen, Germany); e-mail: matthias.groene@fernuni-hagen.de

ИНФОРМАЦИЯ ОБ АВТОРАХ Мейеринг Стефан - доктор экономических наук, профессор, кафедра налогообложения бизнеса факультета экономики, Университет Хаген, г. Хаген, Германия (58084, Германия, г. Хаген, Университетская ул., 65); ORCID: http://orcid.org/0000-0002-8610-8682; e-mail: stephan. meyering@fernuni-hagen.de

Матиас Гроен - докторант, кафедра налогообложения бизнеса факультета экономики, Университет Хаген, г. Хаген, Германия (58084, Германия, г. Хаген, Университетская ул., 65); e-mail: matthias.groene@fernuni-hagen.de

FOR CITATION Meyering S., Groene M. An analysys of the assessment of taxable earnings in Germany. Journal of Tax Reform, 2017, vol. 3, no. 1, pp. 18-28. DOI: 10.15826/itr.2017.3.1.028

ДЛя ЦИТИРОВАНИЯ Мейеринг С. Методы оценки налогооблагаемой прибыли в Германии / С. Мейеринг, М. Гроен / J Journal of Tax Reform. - 2017. - T. 3, № 1. - C. 18-28. - DOI: $\underline{10.15826 / \text { itr.2017.3.1.028 }}$

ARTICLE INFO Received January 25, 2017; accepted March 4, 2017

ИНФОРМАЦИЯ О СТАТЬЕ Дата поступления 25 января 2017 г.; дата принятия к печати 4 марта 2017 г. 